\title{
PENGARUH KOMPETENSI GURU, KOMITMEN KERJA DAN MOTIVASI KERJA TERHADAP KINERJA GURU SMP ANDALAN DI SLEMAN
}

\author{
Yohanes Sukamto, Pardjono \\ SMPN 3 Sleman, \\ Email: sukamtoy55@gmail.com
}

\begin{abstract}
Abstrak
Penelitian ini bertujuan untuk mengungkapkan pengaruh: 1) kompetensi guru, 2) komitmen kerja guru, 3) motivasi kerja, dan 4) kompetensi guru, komitmen kerja, motivasi kerja terhadap kinerja guru di SMP-SMP negeri andalan di Kabupaten Sleman. Penelitian ini merupakan penelitian korelasional. Populasi penelitian ini adalah seluruh guru di SMP negeri andalan se Kabupaten Sleman Tahun Ajaran 2012/2013, meliputi guru-guru di SMPN 1 Godean, SMPN 1 Sleman, SMPN 3 Sleman, SMPN 4 Pakem, SMPN 4 Depok, SMPN 1 Depok, dan SMPN 1 Kalasan sebanyak 262 guru. Sampel sebesar 150 orang ditentukan menggunakan teknik proporsional random sampling. Data dikumpulkan melalui angket dan dianalisis menggunakan teknik analisis regresi ganda. Hasil penelitian menunjukkan bahwa: 1) kompetensi guru berpengaruh positif ( $b 1=0,380)$ dan signifikan ( $\mathrm{p}=0,000)$ terhadap kinerja guru; 2$)$ motivasi kerja berpengaruh positif ( $\mathrm{b} 3=$ $0,262)$ dan signifikan $(\mathrm{p}=0,000)$ terhadap kinerja guru; 3) komitmen kerja berpengaruh positif $(b 2=0,325)$ dan signifikan $(p=0,000)$ terhadap kinerja guru; dan 4$)$ kompetensi guru, komitmen kerja dan motivasi kerja berpengaruh terhadap kinerja guru di SMPSMP negeri andalan di Kabupaten Sleman.
\end{abstract}

Kata kunci: kompetensi guru, komitmen kerja, motivasi kerja, kinerja guru

\section{THE EFFECTS OF COMPETENCE, WORK COMMITMENTS, AND MOTIVATION IN THE WORKPLACE ON THE PERFORMANCE OF THE TEACHERS OF RELIABLE JUNIOR SECONDARY SCHOOLS (SMP) IN SLEMAN DISTRICT}

\begin{abstract}
This study aims to reveal the effects of:1) teacher's competence, 2) teacher's commitment, 3) motivation to work, and 4) teachers' competence, commitment to work, and motivation to work on the performance of teachers of reliable state junior high schools in Sleman District. This study is correlational research. The population in this study was all of the teachers of reliable state SMP's in Sleman District in the academic year of 2012/2013, including teachers of SMPN 1 Godean, SMPN 1 Sleman, SMPN 3 Sleman, SMPN 4 Pakem, SMPN 4 Depok, SMPN 1 Depok and SMPN 1 Kalasan, totaling 262 teachers. A sample of 150 people was established using the proportional random sampling technique. The data were collected through a questionnaire and analyzed using regression analysis techniques. The results show that: 1) teachers' competence has a positive and significant effect $(b 1=0.380)$ and $(p=0.000)$ on teachers' performance; 2$)$ work motivation has a positive and significant effect $(\mathrm{b} 3=0.262)$ and $(\mathrm{p}=0.000)$ on teachers' performance, 3$)$ commitment to work has a positive and significant effect $(b 2=0.325)(p$ $=0.000$ ) on the teachers' performance; and 4) teachers' competence, commitment to work, and motivation to work have an effect on the performance of the teachers of reliable state junior high schools in Sleman District.
\end{abstract}


Keywords: teacher competence, work commitments, work motivation, teacher performance

\section{PENDAHULUAN}

Kualitas pendidikan terus
diupayakan oleh pemerintah dan masyarakat antara lain dengan memperbaiki sistem pendidikan, baik manajemen, kurikulum, sistem evaluasi, peningkatan sarana dan prasarana pendidikan, dan sumber daya manusia. Konsep manajemen berbasis sekolah, Kurikulum berbasis kompetensi yang kemudian diubah menjadi Kurikulum Tingkat Satuan Pendidikan (KTSP), perbaikan sistem Ujian Nasional, sertifikasi guru, dan peningkatan besaran biaya pendidikan merupakan upaya nyata guna memajukan pendidikan di Indonesia. Secara kelembagaan, pemerintah juga menciptakan sekolah-sekolah bertaraf internasional.

Desentralisasi pendidikan telah membuka peluang bagi daerah-daerah untuk mengembangkan sekolah unggulan di daerahnya. Kabupaten Sleman melalui menggunakan konsep sekolah andalan untuk sejumlah sekolah, baik SD, SMP ataupun SMA. Secara bertahap, terdapat 7 (tujuh) SMP di Kabupaten Sleman yang ditunjuk sebagai sekolah andalan. Ketujuh sekolah tersebut adalah: 1) SMP Negeri 1 Kalasan, 2) SMP Negeri 1 Sleman, 3) SMP Negeri 1 Godean, 4) SMP Negeri 4 Pakem, 5) SMP Negeri 1 Depok, 6) SMP Negeri 3 Sleman, dan 7) SMP Negeri 4 Depok. Salah satu pertimbangan ditetapkannya sekolah andalan di Kabupaten Sleman adalah dalam rangka memberdayakan sekolah dan peran serta masyarakat dalam bidang pendidikan untuk meningkatkan mutu pendidikan dan pengelolaan sekolah sebagai model percontohan di Kabupaten Sleman.

Upaya meningkatkan mutu pendidikan tersebut masih belum memberikan hasil yang diharapkan. Proses pembelajaran di SMP Negeri andalan tidak menjamin nilai Ujian Nasional selalu lebih baik dari SMP-SMP lainnya yang bukan andalan. Demikian pula dalam hal prestasi non akademik, SMP Negeri andalan tidak selalu menjadi yang terbaik. Kondisi ini memperlihatkan bahwa pendidikan di SMP negeri andalan belum menunjukkan pendidikan yang berkualitas.

Berbagai upaya tersebut bukan tanpa cela sehingga ada perbaikanperbaikan. Implementasi Rintisan Sekolah Bertaraf Internasional (RSBI) dipandang sebagai bentuk diskriminasi pendidikan. Konsep ideal KTSP juga tidak menjamin pendidikan makin bermutu sehingga sekarang sudah ada sosialisasi Kurikulum 2013 dan sudah mulai diimplementasikan secara terbatas pada sejumlah sekolah di seluruh Indonesia pada tahun ajaran 2013/2014 ini.

Upaya apapun yang dilakukan, ujung tombak pendidikan adalah guru. Guru merupakan figur yang menempati posisi dan berperan penting dalam pendidikan (Hadiyanto, 2004:16). Guru merupakan tenaga profesional yang bertugas merencanakan dan melaksanakan proses pembelajaran, menilai hasil pembelajaran, melakukan pembimbingan dan pelatihan, serta melakukan penelitian dan pengabdian kepada masyarakat. Guru dituntut untuk memiliki kemampuan dasar yang diperlukan sebagai pendidik, pembimbing dan pengajar yang tercermin pada kompetensi guru (Mulyasa, 2009:53).

Kompetensi adalah istilah umum untuk pengetahuan, keterampilan dan sikap yang diperlukan untuk fungsi yang memadai dalam profesi tertentu. Terdapat dua jenis kompetensi guru, yakni kompetensi umum dan kompetensi khusus yang harus dikuasai. Kenyataan di lapangan, termasuk di SMP-SMP Negeri andalan masih ada sejumlah guru yang belum memiliki kompetensi yang memadai. 
Sedangkan upaya guru mengembangkan diri mencerminkan adanya komitmen guru terhadap tugastugasnya. Komitmen meliputi tiga aspek yaitu: 1) komitmen afektif, adalah komitmen yang dilandasi oleh rasa keinginan yang tumbuh dari: identitas kepribadian, kepercayaan, hubungan baik dan keterlibatan personal; 2) komitmen kontinum, yaitu komitmen yang dilandasi preferensi adanya investasi, ketergantungan, dan pengorbanan secara sosial maupun secara ekonomi; 3) komitmen normatif, adalah komitmen yang dilandasi internalisasi norma dan konstruk psikologis organisasi sehingga tumbuh rasa berbagi tanggung jawab. Namun berdasarkan observasi, ternyata masih ada sebagian guru yang kurang memiliki komitmen terhadap tugastugasnya.

Katsva \& Condrey (2005:344) mengatakan: "...motivation is an inducement to action or effort expenditure...". Artinya, motivasi merupakan dorongan untuk bertindak. Dalam kenyataannya di lapangan juga menunjukkan bahwa motivasi kerja guru masih harus ditingkatkan, baik melalui pelatihan atau pemberian tunjangan profesi. Motivasi tidak hanya dari luar tetapi ada pula yang tumbuh dari dalam diri, misalnya keinginan untuk mendapat kepuasan, perasaan berharga, dan mengekspresikan nilai-nilai.

Lain lagi dengan kinerja, Colquit, LePine \& Wesson (2009:37) mendefinisikan kinerja sebagai nilai dari perilaku karyawan atau pekerja yang memberikan kontribusi positif atau negatif terhadap pencapaian tujuan organisasi. Terkait dengan guru, terdapat banyak faktor yang mempengaruhi kinerja guru di antaranya kompetensi guru, komitmen dan motivasi kerja. Westerman \& Simmons (2007:291) meyebutkan terdapat 5 faktor individual yang dapat mempengaruhi kinerja seseorang yaitu: 1) terbuka terhadap pengalaman, 2) kesadaran terhadap ilmu, 3) kesediaan melakukan kegiatan ekstra, 4) kesediaan kerjasama, dan 5) stabilitas emosi.

Berdasarkan hasil survei awal, diketahui kompetensi guru cukup beragam. Terdapat empat kompetensi yang harus dimiliki guru yaitu kompetensi pedagogik, kompetensi kepribadian, kompetensi sosial, dan kompetensi profesional. Kompetensi pedagogik adalah standar kompetensi minimal yang harus dimiliki oleh seorang guru".

Kinerja guru juga dipengaruhi oleh motivasi kerja guru. Motivasi guru digambarkan sebagai keinginan-keinginan dalam diri seorang guru untuk menjalankan pekerjaannya dengan sebaikbaiknya. Guru bekerja di antaranya karena ingin mendapatkan penghasilan, ingin berprestasi, meningkat kariernya. Ketika keinginan tersebut terpenuhi dan menghasilkan perubahan-perubahan, maka guru akan memiliki motivasi kerja yang tinggi. Dalam konteks meningkatkan kinerja guru, aspek motivasi internal dirasa masih kurang diperhatikan padahal suasana batin guru biasanya lebih kuat dan lebih permanen dalam memotivasi guru untuk bekerja. Apabila kinerja guru hanya didasarkan pada motif untuk mendapatkan kompensasi material, maka ketika material yang diharapkan tidak terwujud akan menyebabkan kinerja kembali menurun.

Rosita Bestiana (2012) meneliti Hubungan Kepuasan Kerja, Motivasi dan Komitmen Normatif dengan Kinerja Guru SMPN 1 Rantau Selatan - Labuhan Batu. Penelitian ini bertujuan untuk mendeskripsikan dan mengetahui hubungan antara kepuasan kerja, motivasi dan komitmen normatif dengan kinerja guru SMP Negeri 1 Rantau Selatan Kabupaten Labuhan Batu. Penelitian ini menggunakan model korelasi dengan teknik analisis data deskriptif dan inferensial. Teknik pengumpulan data menggunakan angket. Hasil analisis regresi menyatakan bahwa seluruh variabel yang dianalisis dengan menggunakan uji $\mathrm{F}$ dan hasilnya diperoleh $\mathrm{Fh}>\mathrm{Ft}$. Ini menunjukkan bahwa kepuasan 
kerja guru, motivasi kerja dan komitmen normatif dapat dijadikan sebagai faktor dalam menentukan kinerja guru di SMP Negeri 1 Rantau Selatan Kab. Labuhan Batu.

Purwo Susanto (2010) meneliti tentang Pengaruh Kompetensi dan Motivasi Kerja Terhadap Perilaku Profesional Guru di SMK Gajah Mungkur 1 Wuryantoro Kabupaten Wonogiri. Penelitian ini bertujuan: 1) Untuk mengetahui dan menganalisis ada tidaknya pengaruh kompetensi terhadap perilaku profesional guru di SMK Gajah Mungkur 1 Wuryantoro Kabupaten Wonogiri, 2) Untuk mengetahui dan menganalisis ada tidaknya pengaruh motivasi kerja terhadap perilaku profesional guru di SMK Gajah Mungkur 1 Wuryantoro Kabupaten Wonogiri, 3) Untuk mengetahui dan menganalisis ada tidaknya pengaruh kompetensi dan motivasi kerja secara bersama-sama terhadap perilaku profesional guru di SMK Gajah Mungkur 1 Wuryantoro Kabupaten Wonogiri.

Populasi dalam penelitian ini adalah seluruh guru di SMK Gajah Mungkur 1 Wuryantoro Kabupaten Wonogiri yang berjumlah 34 orang. Variabel dalam penelitian ini adalah kompetensi, motivasi kerja, dan perilaku profesional guru. Metode pengumpulan data yang digunakan adalah dokumentasi, wawancara dan kuesioner. Metode analisis data yang digunakan adalah analisis statistik regresi berganda. Hasil penelitian menunjukkan bahwa ada pengaruh yang signifikan antara kompetensi dan motivasi kerja terhadap perilaku profesional guru baik secara simultan maupun secara parsial. Dari hasil analisis rergresi didapatkan persamaan $\mathrm{Y}=$ $1,639+0,452 X 1+0,154 X 2$. Secara parsial besarnya pengaruh variabel kompetensi guru terhadap variable perilaku profesional guru sebesar 46,51\%, pengaruh variabel motivasi kerja ini terhadap variabel perilaku profesional guru sebesar 18,84\%. Besarnya pengaruh variabel kompetensi guru dan variabel motivasi kerja secara simultan sebesar $69,2 \%$. Simpulan dalam penelitian ini adalah kompetensi dan motivasi kerja secara simultan dan parsial berpengaruh signifikan terhadap perilaku profesional guru di SMK Gajah Mungkur 1 Wuryantoro Kabupaten Wonogiri.

\section{METODE}

Jenis atau Desain Penelitian

Penelitian ini menggunakan jenis penelitian korelasional, yakni mencari hubungan antara dua variabel atau lebih. Dalam penelitian ini terdapat tiga variabel bebas dan satu variabel terikat. Variabel bebas yaitu kompetensi guru yang dinyatakan sebagai $\mathrm{X}_{1}$, komitmen kerja sebagai $\mathrm{X}_{2}$, motivasi kerja guru dinyatakan sebagai $X_{3}$. Variabel terikat yaitu kinerja guru dinyatakan sebagai $\mathrm{Y}$. Metode pendekatan yang dipakai adalah pendekatan kuantitatif.

Tempat dan Waktu Penelitian

Penelitian dilaksanakan di 7 (tujuh) SMP negeri andalan di Kabupaten Sleman Tahun Ajaran 2011/2012 yaitu SMPN 1 Godean, SMPN 1 Sleman, SMPN 3 Sleman, SMPN 4 Pakem, SMPN 4 Depok, SMPN 1 Depok, dan SMPN 1 Kalasan. Sedangkan waktu pelaksanaan penelitian pada bulan Juni 2013 sampai dengan bulan Juli 2013.

Populasi dan Sampel

Populasi pada penelitian ini adalah seluruh guru di SMP Negeri andalan se Kabupaten Sleman Tahun Ajaran 2012/2013 sebanyak 262 guru. Sampel diambil dengan teknik proporsional random sampling. Sehubungan dengan jumlah populasi 262 orang, maka ditentukan jumlah sampel menurut tabel penentuan jumlah sampel dari Isaac dan Michael berdasarkan tingkat kesalahan $5 \%$ yaitu sebanyak 150 orang sebagaimana tertuang dalam Tabel 1. 
Tabel 1. Data Sampel Penelitian

\begin{tabular}{clcc}
\hline No & Nama Sekolah & $\begin{array}{c}\text { Jumlah } \\
\text { populasi }\end{array}$ & $\begin{array}{c}\text { Jumlah } \\
\text { sampel }\end{array}$ \\
\hline 1 & SMP Negeri 1 Godean & 34 & 19 \\
2 & SMP Negeri 1 Sleman & 43 & 25 \\
3 & SMP Negeri 3 Sleman & 43 & 25 \\
4 & SMP Negeri 4 Pakem & 27 & 15 \\
5 & SMP Negeri 4 Depok & 27 & 15 \\
6 & SMP Negeri 1 Depok & 45 & 26 \\
7 & SMP Negeri 1 Kalasan & 43 & 25 \\
\hline & Jumlah & 262 & 150 \\
\hline
\end{tabular}

Teknik Pengumpulan Data

Dalam penelitian ini metode yang digunakan adalah metode penelitian deskriptif kuantitatif dengan analisis regresi linier berganda. Metode deskriptif dirancang untuk mengetahui ada tidaknya hubungan antar gejala (variabel), hubungan tersebut positif atau negatif dan seberapa signifikan hubungan antar variabel tersebut.

Instrumen Pengumpulan Data

Penelitian ini menggunakan instrumen berupa kuesioner tertutup dengan bentuk Rating Scale (skala bertingkat). Untuk menentukan skor atau nilai jawaban angket, digunakan Skala Likert dengan lima atau empat kategori.

Instrumen kompetensi guru disusun sebanyak 30 butir pernyataan berdasarkan empat indikator yaitu 1) kompetensi pedagogik, 2) kompetensi professional, 3) kompetensi kepribadian, dan 4) kompetensi sosial. Instrumen komitmen guru disusun sebanyak 25 butir pernyataan berdasarkan variabel serta indikator: 1) komitmen terhadap profesinya sebagai guru, 2) komitmennya terhadap proses belajar mengajar, 3) komitmen terhadap kebijakan sekolah.

Instrumen motivasi kerja guru disusun sebanyak 40 butir pernyataan berdasarkan variabel serta indikator: 1) usaha, 2) daya tahan, 3) sasaran kerja, 4) kepuasan kerja, 5) gaji, 6) kualitas pengawasan, 7) hubungan antar teman sejawat, dan 8) kondisi kerja dan keamanan fisik sekolah.

Instrumen kinerja guru disusun sebanyak 30 butir pernyataan berdasarkan variabel serta indikator yang akan diukur:
1) kualitas kerja, 2) kuantitas kerja, 3) kehadiran, dan 4) inisiatif.

Validitas dan Reliabilitas Instrumen

Butir-butir instrumen pernyataan tidak langsung digunakan dilapangan penelitian, tetapi harus dilkukan pengujian melalui uji validitas dan reliabilitas instrumen.

1. Uji Validitas dan Reliabilitas Instrumen a. Uji Validitas Instrumen

Uji validitas atau kesahihan digunakan untuk mengetahui seberapa tepat suatu alat ukur melakukan fungsi pengukuran. Menurut Sugiyono (2008:123), suatu instrumen non-tes yang digunakan untuk mengukur sikap atau persepsi harus memenuhi syarat validitas konstruksi (construct validity), hal itu dilakukan melalui pertimbangan ahli (expert judgement), selanjutnya dilakukan uji empiris dan terakhir dilakukan uji validitas isi. Untuk menguji validitas isi digunakan rumus korelasi Product Moment Pearson menggunakan program Statistical Product and Service Solutions (SPSS) for windows. Rumus Korelasi Product Moment (Hinkle, Wiersman \& Jurs, 1979:96):

$$
r=\frac{N \sum X Y-\sum X \sum Y}{\sqrt{\left.\left[N \sum X^{2}-\left(\sum X\right)^{2}\right] N \sum Y^{2}-\left(Y \sum Y\right)^{2}\right]}}
$$

Keterangan :

$r \quad$ : koefisien korelasi antara $\mathrm{x}$ dan $\mathrm{y}$

$\mathrm{X}$ : Total dari setiap item

$\mathrm{X}^{2} \quad$ : Total kuadrat dari setiap item

Y : Total dari total item

$\mathrm{Y}^{2}$ : Total kuadrat dari total item

$\sum \mathrm{XY}=$ Product dari deviasi $\mathrm{X}$ kali deviasi Y

Hasil perhitungan angket yang telah diujicobakan dibanding angka kritik dari tabel product moment dengan taraf signifikansi $5 \%$ serta dengan kriteria pengujian jika harga $r$ hitung $>\mathrm{r}$ tabel product moment maka item angket tersebut valid, dan apabila $r$ hitung, $<\mathrm{r}$ tabel berarti angket tersebut tidak valid. Suatu butir dikatakan valid 
jika mencapai nilai koefisien (r) = 0,300 (Saifudin Azwar, 2003:65).

b. Uji Reliabilitas Angket

Reliabilitas dilakukan untuk mengetahui sejauh mana hasil pengukuran suatu alat ukur dapat diandalkan. Untuk menguji reliabilitas digunakan rumus Cronbach Alpha. Adapun rumusnya adalah sebagai berikut :

$\mathrm{r}_{i i}=\left[\frac{\mathrm{k}}{\mathrm{k}-1}\right]\left[1-\frac{\Sigma \sigma_{\mathrm{b}}{ }^{2}}{\sigma_{\mathrm{t}}{ }^{2}}\right]$

Keterangan :

$\mathrm{r}_{\mathrm{ii}}=$ reliabilitas instrumen

$\mathrm{k} \quad$ = banyaknya butir pertanyaan atau banyaknya soal

$\sum \sigma b^{2}=$ jumlah varians butir

$\sigma \mathrm{t}^{2}=$ varians total

Angket dikatakan reliabel jika $\mathrm{r}$ hitung $>\mathrm{r}$ tabel dan jika $\mathrm{r}$ hitung $<\mathrm{r}$ tabel maka angket tidak reliabel. Suatu instrumen dikatakan memiliki reliabilitas yang tinggi jika nilai koesfisien alpha lebih besar dari 0,70.

\section{c. Revisi Angket}

Revisi angket dilakukan dengan menghilangkan butir soal yang tidak valid maupun tidak reliabel sehingga memenuhi syarat validitas dan reliabilitas angket.

\section{d. Memperbanyak dan Menyebarkan angket}

2. Hasil Uji Validitas dan Reliabilitas Instrumen

a. Kompetensi guru

Jumlah item skala kompetensi guru adalah 30 item dimana ada 29 item valid dan 1 item gugur. Koefisien validitas antara 0,449 sampai dengan 0,864 dan koefisien reliabilitas 0,947, sehingga data yang dikumpulkan dari skala kompetensi guru yang terdiri 29 item layak digunakan dalam penelitian. b. Komitmen kerja

Jumlah item skala komitmen kerja adalah 25 item dimana ada 23 item valid dan 2 item gugur. Koefisien validitas antara 0,452 sampai dengan 0,724 dan koefisien reliabilitas 0,909, sehingga data yang dikumpulkan dari skala komitmen kerja yang terdiri 23 item layak digunakan dalam penelitian.

\section{c. Motivasi kerja guru}

Jumlah item skala motivasi kerja adalah 40 item dimana ada 36 item valid dan 4 item gugur. Koefisien validitas antara 0,400 sampai dengan 0,878 dan koefisien reliabilitas 0,948 , sehingga data yang dikumpulkan dari skala motivasi kerja guru yang terdiri 36 item layak digunakan dalam penelitian.

\section{d. Kinerja guru}

Jumlah item skala kinerja guru adalah 30 item dimana ada 27 item valid dan 3 item gugur. Koefisien validitas antara 0,498 sampai dengan 0,873 dan koefisien reliabilitas 0,950 , sehingga data yang dikumpulkan dari skala kinerja guru yang terdiri 27 item layak digunakan dalam penelitian.

Teknik Analisis Data

Teknik analisis data dalam penelitian ini menggunakan statistik. Statistik yang digunakan adalah statistik deskriptif dan statistik inferensial sebagai berikut:

1. Statistik deksriptif.

Statistik deskriptif digunakan untuk mengetahui kontribusi jawaban responden pada setiap variabel yang akan ditampilkan dalam bentuk tabulasi. Data dari setiap variabel dianalisis dengan analisis deskriptif untuk menentukan nilai rata-rata dan nilai simpangan baku. Kemudian dikelompokkan menjadi empat kategori yaitu sangat baik, baik, cukup, dan kurang.

Interval $=\frac{\text { skor } \text { maksimal }- \text { skor } \text { min } \text { imal }}{\text { banyaknyakelas }}$ 


\section{Statistik inferensial}

Statistik inferensial digunakan untuk menganalisis data sampel dan hasilnya diberlakukan untuk populasi menggunakan statistik parametris yang mensyaratkan bahwa data setiap variabel yang akan dianalisis harus berdistribusi normal.

\section{Uji Prasyarat Analisis}

Teknik analisis regresi dilakukan sesuai uji persaratan analisis. Hal ini bertujuan untuk memenuhi persyaratan analisis regresi. Persyaratan analisis regresi adalah: 1) uji normalitas, 2) linieritas dan keberartian, dan 3) homosedastisitas. Berdasarkan pemikiran di atas, maka analisis regeresi akan didahului dengan uji pra syarat yaitu uji normalitas, linieritas, homosedastisitas, dan koefisien regeresi.

a. Uji Normalitas

Uji normalitas dimaksudkan untuk mengetahui apakah data yang akan dianalisis berbentuk sebaran normal atau tidak dengan menggunakan uji normalitas Chi-Kuadrat. Kriteria uji, jika $X^{2}$ hitung $<X^{2}$ tabel, maka sampel berdistribusi normal dan sebaliknya apabila $X^{2}$ hitung $>X^{2}$ tabel, maka data yang diperoleh tidak berdistribusi normal.

Rumus Chi kuadrat :

$$
\chi^{2}=\sum_{i=1}^{k} \frac{(O i-E i)^{2}}{E i}
$$

Untuk mengetahui kenormalan data maka dapat dilihat dari nilai 2tailed $>(\alpha=0,05)$.

b. Uji Linearitas dan Keberartian

Uji linieritas digunakan untuk mengetahui penyebaran data apakah data telah disekitar garis lurus persamaan ataukah tidak. Apabila disekitar garis lurus persamaan maka hubungan fungsional antara variabel $\mathrm{X}$ dan $Y$ adalah linear. Uji linearitas variabel $\mathrm{X}_{1}$ terhadap $\mathrm{Y}$, Variabel $\mathrm{X}_{2}$ terhadap $\mathrm{Y}$, dan Variabel $\mathrm{X}_{3}$ terhadap $\mathrm{Y}$ dapat dilakukan dengan menggunakan program SPSS 13 for windows. Pengujian linieritas hubungan antara variabel dilakukan dengan menentukan persamaan garisnya terlebih dahulu. Persamaan regresi variabel $\mathrm{X}$ dan variabel $\mathrm{Y}$ adalah $\mathrm{Y}=\mathrm{ax}+\mathrm{k}$. Kemudian untuk mencari nilai $\mathrm{F}$ digunakan rumus di bawah ini :

$$
F=\frac{\frac{x_{1}^{2}}{k-2}}{\frac{x_{2}^{2}}{N-k}}
$$

Keterangan :

$\mathrm{F}=$ nilai $\mathrm{F}$ untuk Regresi Linier

$\mathrm{K}=$ jumlah kelompok pengamatan

$\mathrm{N}=$ banyaknya responden

Linier atau tidak variabel-variabel penelitian ini dapat dilihat dari nilai $\mathrm{p}<$ $(0,05)$.

c. Uji Homosedastisitas

Persyaratan homosedastisitas adalah variasi nilai-nilai $\mathrm{Y}$ di sekitar garis regeresi. Homosedastisitas bertujuan untuk menentukan variasi nilai-nilai $\mathrm{Y}$ sekitar garis regeresi harus konstan (uniform/seragam) untuk setiap X. Uji homosedastisitas ini menggunakan uji jenjang Spearman sebagai berikut:

$$
r_{s}=1-6\left[\frac{\sum d i^{2}}{N\left(N^{2}-1\right)}\right]
$$

Keterangan:

$d i=$ perbedaan dalam rank yang ditetapkan untuk dua karakteristik yang berbeda dari individual atau fenomena ke i

$\mathrm{N}=$ Banyaknya individual atau fenomena yang di rank

Keterangan:

Jika rs lebih besar dari $\mathrm{r}$ tabel, maka terjadi heterosedastisitas.

Jika rs lebih kecil dari $r$ tabel, maka terjadi homosedastisitas. 
d. Koefisien Korelasi Linier

Penggunaaan analisis regresi untuk menentukan pengaruh variabel bebas $X_{1}, X_{2}, X_{3}$ terhadap variabel terikat $\mathrm{Y}$, terlebih dahulu perlu diketahui seberapa kuat hubungan antara variabel-variabel tersebut. Formula yang digunakan untuk menentukan koofesien korelasi adalah korelasi product moment Karl Pearson. Dengan demikian dibuktikan bahwa koefisien terkecil bernilai -1 dan terbesar bernilai 1 .

\section{e. Uji Independensi}

Uji independensi digunakan untuk menguji apakah ada hubungan antara dua faktor variabel dalam penelitian. Apabila hasil pengujian tersebut tidak terdapat kaitan, dapat dikatakan faktor-faktor tersebut bersifat independen atau bebas stastistik. Rumus yang digunakan untuk menguji independensi yaitu Rumus Product Moment dengan menggunakan program SPSS.

\section{Uji Analisis Regresi}

Langkah selanjutnya adalah menentukan persamaan regresi secara parsial dan bersama-bersama antara $X_{1}$ terhadap $\mathrm{Y}, \mathrm{X}_{2}$ terhadap $\mathrm{Y}$, dan $\mathrm{X}_{3}$ terhadap $Y$ serta $X_{1}, X_{2}$, dan $X_{3}$ terhadap variabel $\mathrm{Y}$. Menentukan analisis regeresi untuk menguji hipotesis penelitian yang telah dirumuskan. Proses pembuktian dengan menggunakan uji $t$ dan uji F.

Uji hipotesis dilakukan sesuai dengan interpretasi terhadap keluaran perhitungan dengan program SPSS.

\section{Uji t}

Uji t dugunakan untuk menguji signifikansi pengaruh variabel $\mathrm{X}_{1}, \mathrm{X}_{2}$, dan $\mathrm{X}_{3}$ terhadap variabel $\mathrm{Y}$ secara parsial, sesuai dengan rumusan hipotesis sebagai berikut:

1) Ho: tidak ada pengaruh faktor

kompetensi guru terhadap

kinerja guru kompetensi guru terhadap kinerja guru

2) Ho: tidak ada pengaruh faktor komitmen terhadap kinerja guru

Ha: ada pengaruh faktor komitmen terhadap kinerja guru

3) Ho: tidak ada pengaruh faktor motivasi kerja guru terhadap kinerja guru

Ha: ada pengaruh faktor motivasi kerja guru terhadap kinerja guru

Untuk pengujian hipotesis dilakukan dengan uji $t$ statistik ( $t$ tes), uji $t$ statistik digunakan untuk menguji signifikansi konstanta dan variabel independent apakah berpengaruh terhadap variabel dependent.

Uji t dengan rumus $t=\frac{r_{s} \sqrt{N-2}}{\sqrt{N-r_{s}^{2}}}$ dengan derajat kebebasan N-2.

\section{Uji F}

Uji $F$ digunakan untuk menguji signifikansi secara bersama-sama variabel $\mathrm{X}_{1}, \mathrm{X}_{2}$, dan $\mathrm{X}_{3}$ terhadap $\mathrm{Y}$. Hipotesis yang diuji adalah sebagai berikut:

$\mathrm{H}_{\mathrm{o}}$ : tidak ada pengaruh secara bersamasama faktor kompetensi guru, komitmen dan motivasi kerja guru terhadap kinerja guru

$\mathrm{H}_{\mathrm{a}}$ : ada pengaruh secara bersama-sama faktor kompetensi guru, komitmen dan motivasi kerja guru terhadap kinerja guru.

Hasil perhitungan diinterpretasikan dengan $\mathrm{F}$ hitung dan $\mathrm{F}$ tabel. Apabila $\mathrm{F}$ hitung $>$ $\mathrm{F}$ tabel maka hipotesis $\mathrm{H}_{\mathrm{a}}$ diterima. Adapun langkah-langkah yang ditempuh dalam regresi ganda lima prediktor yaitu;

1) Membuat persamaan regresi ganda yang rumusnya dapat dinyatakan sebagai berikut:

$$
\mathrm{Y}=\mathrm{a}+\mathrm{b}_{1} \mathrm{X}_{1}+\mathrm{b}_{2} \mathrm{X}_{2}+\mathrm{b}_{3} \mathrm{X}_{3}
$$

Ha: ada pengaruh faktor 
2) Mencari koefisien korelasi ganda antara kriterium $\mathrm{Y}$ dengan prediktor $\mathrm{X}_{1}, \mathrm{X}_{2}, \mathrm{X}_{3}$ dengan rumus:

$\mathrm{R}_{\mathrm{y}}(123)=\sqrt{\frac{\mathrm{b}_{1} \sum \mathrm{x}_{1} \mathrm{y}+b_{2} \sum \mathrm{x}_{2} \mathrm{y}+b_{3} \sum x_{3} y}{\sum \mathrm{Y}^{2}}}$

Keterangan:

$\mathrm{b}_{1}=$ koefisien prediktor $\mathrm{x}_{1}$

$\mathrm{b}_{2}=$ koefisien prediktor $\mathrm{x}_{2}$

$\mathrm{b}_{3}=$ koefisien prediktor $\mathrm{x}_{3}$

$\sum \mathrm{x} 1 \mathrm{y}=$ jumlah skor variabel kompetensi guru dikalikan dengan jumlah skor variabel kinerja guru

$\sum \mathrm{x}_{2} \mathrm{y}=$ jumlah skor variabel komitmen guru dikalikan dengan jumlah skor variabel kinerja guru

$\sum \mathrm{x}_{3} \mathrm{y}=$ jumlah skor variabel motivasi guru dikalikan dengan jumlah skor variabel kinerja guru

$\sum \mathrm{y}^{2}=$ jumlah kuadrat kriterium variabel kinerja guru

\section{HASIL DAN PEMBAHASAN}

Hasil Penelitian dan Analisis Deskriptif

a. Kompetensi guru

Skor total kompetensi guru berkisar antara 45 sampai 126 dengan rata-rata 87,85. Adapun distribusi frekuensi dari kompetensi guru dapat dilihat pada tabel 2.

Tabel 2. Distribusi Frekuensi Variabel

Kompetensi Guru

\begin{tabular}{lccc}
\hline Kategori & Interval & $\begin{array}{c}\text { Freku- } \\
\text { ensi (F) }\end{array}$ & $\begin{array}{c}\text { Prosen } \\
\text {-tase } \\
(\%)\end{array}$ \\
\hline Sangat & $116-145$ & & \\
baik & & 5 & 3,3 \\
Baik & $87-115$ & 74 & 49,3 \\
Cukup & $58-86$ & 63 & 42,0 \\
Kurang & $29-57$ & 8 & 5,3 \\
\hline & Total & 150 & 100 \\
\hline
\end{tabular}

Berdasarkan tabel di atas dapat diketahui bahwa distribusi variabel kompetensi guru sebagian besar dalam kategori baik yaitu 49,3\%, kemudian diikuti kategori cukup sebanyak 42,0\%, kategori kurang sebanyak 5,3\% dan terakhir kategori sagat baik sebanyak 3,3\%. Rata-rata kompetensi guru sebesar 87,85 berada dalam interval 87 - 115 sehingga kapasitas guru untuk melakukan sesuatu, yang dihasilkan dari proses belajar guru SMP-SMP Negeri andalan di Kabupaten Sleman adalah baik. Kompetensi guru SMP-SMP Negeri andalan di Kabupaten Sleman yang ini meliputi kompetensi profesional, kompetensi pedagogik, kompetensi kepribadian dan kompetensi sosial termasuk dalam baik.

b. Komitmen kerja

Skor total komitmen kerja berkisar antara 35 sampai 104 dengan rata-rata 68,66 .

Tabel 3. Distribusi Frekuensi Variabel

Komitmen Kerja

\begin{tabular}{lccc}
\hline Kategori & Interval & $\begin{array}{r}\text { Frekue } \\
\text { nsi (F) }\end{array}$ & $\begin{array}{c}\text { Prosen } \\
\text { tase } \\
(\%)\end{array}$ \\
\hline Sangat baik & $92-115$ & 6 & 4,0 \\
Baik & $69-91$ & 66 & 44,0 \\
Cukup & $46-68$ & 74 & 49,3 \\
Kurang & $23-45$ & 4 & 2,7 \\
\hline Total & & 150 & 100,0 \\
\hline
\end{tabular}

Berdasarkan tabel di atas dapat diketahui bahwa distribusi variabel komitmen kerja sebagian besar dalam kategori cukup yaitu 49,3\%. Rata-rata komitmen kerja sebesar 68,66 mendekati dalam batas cukup maupun baik sehingga ikatan kesetiaan guru SMP-SMP Negeri andalan di Kabupaten Sleman terhadap nilai-nilai (afeksi) profesi, kelangsungan sekolah sebagai tempat proses belajar mengajar, dan kebijakan-kebijakan di bidang pendidikan yang harus dilaksanakannya. Komitmen guru SMP-SMP Negeri andalan di Kabupaten Sleman terhadap proses belajar mengajar, kurikulum dam kebijakan sekolah termasuk cukup baik.

c. Motivasi kerja guru

Skor total motivasi kerja guru berkisar antara 56 sampai 158 dengan rata-rata 110,87. Adapun distribusi frekuensi dari motivasi kerja guru dapat dilihat pada tabel 4. Berdasarkan tabel 4 
dapat diketahui bahwa distribusi variabel motivasi kerja guru sebagian besar dalam kategori baik yaitu 51,3\%, kemudian diikuti kategori cukup sebanyak 43,3\%, kategori sangat baik 3,3\% dan terkahir kategori kurang sebanyak 2,0\%. Rata-rata motivasi kerja guru sebesar 110,87 berada dalam interval 108 - 143 sehingga daya, kekuatan, dorongan, yang berasal dari dalam diri seorang guru yang ikut menyebabkan terwujudnya prestasi kerja (kinerja) untuk melaksanakan tugas mengajar dan mendidik secara sistematis sesuai dengan kebutuhan, harapan, dan tujuan yang telah ditetapkan guru SMPSMP Negeri andalan di Kabupaten Sleman adalah baik.

Tabel 4. Distribusi Frekuensi Variabel Motivasi Kerja Guru

\begin{tabular}{lccc}
\hline \multicolumn{1}{c}{ Kategori } & Interval & $\begin{array}{l}\text { Frekuen } \\
\text { si (F) }\end{array}$ & $\begin{array}{c}\text { Prosentase } \\
(\%)\end{array}$ \\
\hline Sangat baik & $144-180$ & 5 & 3,3 \\
Baik & $108-143$ & 77 & 51,3 \\
Cukup & $72-107$ & 65 & 43,3 \\
Kurang & $36-71$ & 3 & 2,0 \\
\hline Total & & 150 & 100,0 \\
\hline
\end{tabular}

Usaha individu, daya tahan/keuletan, sasaran kerja, kepuasan kerja, gaji yang diterima, kualitas pengawasan, hubungan antar teman sejawat kondisi kerja dan keamanan fisik oleh pihak sekolah guru SMP-SMP Negeri andalan di Kabupaten Sleman termasuk baik.

\section{d. Kinerja guru}

Skor total kinerja guru berkisar antara 41 sampai 121 dengan rata-rata 85,91 . Adapun distribusi frekuensi dari kinerja guru dapat dilihat pada tabel 5 .

Tabel 5. Distribusi Frekuensi Variabel Kinerja Guru

\begin{tabular}{|c|c|c|c|}
\hline Kategori & Interval & $\begin{array}{l}\text { Frekuensi } \\
(\mathrm{F})\end{array}$ & $\begin{array}{c}\text { Prosen } \\
\text { tase }(\%)\end{array}$ \\
\hline Sangat baik & $108-135$ & 8 & 5,3 \\
\hline Baik & $81-107$ & 80 & 53,3 \\
\hline Cukup & $54-80$ & 58 & 38,7 \\
\hline \multirow[t]{2}{*}{ Kurang } & $27-53$ & 4 & 2,7 \\
\hline & Total & 150 & 100,0 \\
\hline
\end{tabular}

Berdasarkan tabel di atas dapat diketahui bahwa distribusi variabel kinerja guru sebagian besar dalam kategori baik yaitu 53,3\%, kemudian diikuti kategori cukup sebanyak 38,7\%, kategori sangat baik sebanyak 5,3\% dan terakhir kategori kurang sebanyak 2,7\%. Rata-rata kinerja guru sebesar 85,91 berada dalam interval 81 - 107 sehingga kerja guru SMP-SMP Negeri andalan di Kabupaten Sleman yang terefleksi secara sadar, sistematis dalam cara merencanakan, melaksanakan, menilai, dan mengevaluasi pembelajaran adalah baik. Kualitas kerja, kuantitas kerja, ketepatan waktu dalam pelaksanaan, kehadiran dan inisiatif dalam bekerja guru SMP-SMP Negeri andalan di Kabupaten Sleman dapat dikatakan dalam kategori baik.

Uji Prasyarat

Uji prasyarat yang terdiri dari uji normalitas, uji linearitas dan uji heterosedastisitas.

a. Uji Normalitas

Uji normalitas digunakan untuk mengetahui apakah model regresi berdistribusi normal atau tidak menggunakan Chi Square yaitu membandingkan nilai probabilitas dengan nilai kritisnya yaitu 0,05 .

Tabel 6. Hasil Uji Chi Square

\begin{tabular}{lcc}
\hline \multicolumn{1}{c}{ Variabel } & $\chi^{2}$ & $\mathrm{p}$ \\
\hline Kompetensi guru $\left(\mathrm{X}_{1}\right)$ & 3,880 & 0,567 \\
Komitmen kerja $\left(\mathrm{X}_{2}\right)$ & 2,519 & 0,774 \\
Motivasi kerjaguru $\left(\mathrm{X}_{3}\right)$ & 7,101 & 0,213 \\
Kinerja guru $(\mathrm{Y})$ & 5,951 & 0,311 \\
\hline
\end{tabular}

Berdasarkan hasil perhitungan di atas nilai p pada semua variabel lebih besar dari 0,05 maka data untuk keempat variabel yaitu kompetensi guru, komitmen kerja, motivasi kerja guru dan kinerja guru terdistribusi normal.

\section{b. Uji Linearitas}

Pedoman yang digunakan untuk menguji linieritas garis regresi dilakukan dengan jalan menguji signifikansi nilai $F$. 
Adapun hasil uji linieritas hubungan dapat dilihat pada Tabel 7.

Berdasarkan hasil perhitungan di atas nilai $\mathrm{p}$ pada hubungan antara kompetensi guru dan kinerja guru sebesar $0,328(\mathrm{p}>0,05)$ sehingga hubungan antara kedua variabel tersebut linear. Nilai p pada hubungan antara komitmen kerja dan kinerja guru sebesar 0,342 ( $\mathrm{p}>0,05)$ sehingga hubungan antara kedua variabel tersebut linear.

Tabel 7. Hasil Uji Linieritas

\begin{tabular}{lcc}
\hline \multicolumn{1}{c}{ Hubungan } & $\mathrm{F}$ & $\mathrm{p}$ \\
\hline $\begin{array}{l}\text { Kompetensi guru }\left(\mathrm{X}_{1}\right) \\
\text { dan kinerja guru }(\mathrm{Y})\end{array}$ & 1,107 & 0,328 \\
$\begin{array}{l}\text { Komitmen kerja }\left(\mathrm{X}_{2}\right) \text { dan } \\
\text { kinerja guru }(\mathrm{Y})\end{array}$ & 1,098 & 0,342 \\
$\begin{array}{l}\text { Motivasi kerja guru }\left(\mathrm{X}_{3}\right) \\
\text { dan kinerja guru }(\mathrm{Y})\end{array}$ & 1,136 & 0,291 \\
\hline
\end{tabular}

Nilai p pada hubungan antara motivasi kerja guru dan kinerja guru sebesar 0,291 $(\mathrm{p}>0,05)$ sehingga hubungan antara kedua variabel tersebut linear.

\section{c. Uji Homosedastisitas}

Analisis ada atau tidaknya problem homosedastisitas dilakukan dengan menggunakan uji jenjang Spearmen. Adapun hasil uji homosedastisitas hubungan dapat dilihat pada tabel 8 .

Tabel 8. Hasil Uji Linieritas

\begin{tabular}{lcc}
\hline \multicolumn{1}{c}{ Hubungan } & $\mathrm{r}$ & $\mathrm{p}$ \\
\hline $\begin{array}{l}\text { Kompetensi guru (X } \\
\text { dan nilai residu (Y') }\end{array}$ & 0,042 & 0,606 \\
$\begin{array}{l}\text { Komitmen kerja (X } \\
\text { dan nilai residu (Y') }\end{array}$ & 0,064 & 0,440 \\
$\begin{array}{l}\text { Motivasi kerja guru (X) } \\
\text { dan nilai residu (Y') }\end{array}$ & 0,038 & 0,643 \\
\hline
\end{tabular}

Besarnya nilai $r_{s}$ hitung untuk $n=150$ adalah 0,159. Berdasarkan hasil perhitungan di atas nilai $r_{s}$ pada variabel kompetensi guru sebesar 0,042 $\left(\mathrm{r}_{\mathrm{s}}<\right.$ $0,159)$ maka terjadi homosedastisitas. Nilai $r_{s}$ pada variabel komitmen kerja sebesar $0,064\left(\mathrm{r}_{\mathrm{s}}<0,159\right)$ maka terjadi homosedastisitas. Nilai $\mathrm{r}_{\mathrm{s}}$ pada variabel motivasi kerja guru sebesar 0,038 $\left(\mathrm{r}_{\mathrm{s}}<\right.$ $0,159)$ maka terjadi homosedastisitas.
Uji hipotesis

Pengujian hipotesis dilaksanakan untuk membuktikan apakah hipotesis yang diajukan yang sifatnya sementara benarbenar terbukti atau tidak. Persyaratan uji normalitas, uji linieritas, uji homosedastisitas, uji koefisien linear dan uji independensi sudah terpenuhi dan untuk mengetahui pengaruh antar variabel bebas dengan variabel terikat maka dilakukan uji hipotesis. Penelitian ini menggunakan teknik analisis regresi ganda dengan tiga prediktor untuk mengetahui pengaruh variabel bebas secara sendiri-sendiri maupun bersamasama variabel kompetensi guru $\left(\mathrm{X}_{1}\right)$, komitmen kerja $\left(\mathrm{X}_{2}\right)$ dan motivasi kerja guru $\left(\mathrm{X}_{3}\right)$ terhadap variabel terikat kinerja guru $(\mathrm{Y})$.

Tabel 9. Hasil Uji t pada Analisis Regresi Linear Berganda

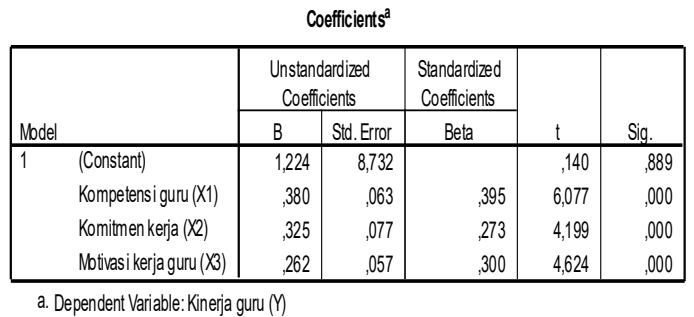

Berdasarkan tabel hasil uji analisis regresi linear berganda di atas dapat dirumuskan model persamaan regresi linear berganda sebagai berikut:

$\mathrm{Y}=1,224+0,380 \mathrm{X}_{1}+0,325 \mathrm{X}_{2}+$ $0,262 X_{3}$

Berdasarkan persamaan regresi di atas dapat dijelaskan sebagai berikut:

a. Konstanta regresi bernilai 1,224 artinya taksiran besarnya kinerja guru tanpa ada pengaruh dari variabel lain (kompetensi guru, komitmen kerja, dan motivasi kerja guru) sebesar 1,224.

b. Koefisien kompetensi guru bernilai 0,380 artinya apabila kompetensi guru bertambah $1 \%$ maka kinerja guru juga bertambah 38,0\%, tetapi apabila kompetensi guru berkurang satu satuan maka kinerja guru juga akan berkurang $38,0 \%$. 
c. Koefisien komitmen kerja bernilai 0,325 artinya apabila komitmen kerja bertambah $1 \%$, maka kinerja guru juga bertambah 32,5\%. Tetapi apabila komitmen kerja berkurang satu satuan maka kinerja guru juga akan berkurang $32,5 \%$.

d. Koefisien motivasi kerja guru bernilai 0,262 artinya apabila motivasi kerja guru bertambah $1 \%$ maka kinerja guru juga bertambah $26,2 \%$, tetapi apabila motivasi kerja guru berkurang satu satuan maka kinerja guru juga akan berkurang $26,2 \%$.

Uji $\mathrm{t}$ digunakan untuk mengetahui pengaruh variabel independent $\left(\mathrm{X}_{1}, \mathrm{X}_{2}\right.$ dan $\mathrm{X}_{3}$ ) secara parsial terhadap variabel dependent (Y).

a. Kompetensi guru $\left(\mathrm{X}_{1}\right)$ mempunyai pengaruh positif yang signifikan terhadap kinerja guru (Y), hal ini dapat terlihat dari nilai thitung $=6,077$ dan nilai sig $=0,000(p<0,05)$. Hipotesis pertama "Kompetensi guru berpengaruh terhadap kinerja guru di SMP-SMP Negeri andalan di Kabupaten Sleman" terbukti kebenarannya.

b. Komitmen kerja $\left(\mathrm{X}_{2}\right)$ mempunyai pengaruh positif yang signifikan terhadap kinerja guru (Y), hal ini dapat terlihat dari nilai thitung $=4,199$ dan nilai $\operatorname{sig}=0,000(p<0,05)$. Hipotesis kedua "Komitmen kerja berpengaruh terhadap kinerja guru di SMP-SMP Negeri andalan di Kabupaten Sleman" terbukti kebenarannya.

c. Motivasi kerja guru $\left(\mathrm{X}_{3}\right)$ mempunyai pengaruh positif yang signifikan terhadap kinerja guru (Y), hal ini dapat terlihat dari nilai thitung $=4,624$ dan nilai $\operatorname{sig}=0,000(\mathrm{p}<0,05)$. Hipotesis ketiga "Motivasi kerja guru berpengaruh terhadap kinerja guru di SMP-SMP negeri andalan di Kabupaten Sleman" terbukti kebenarannya.

Uji F

Uji $\mathrm{F}$ digunakan untuk mengetahui pengaruh variabel independent $\left(\mathrm{X}_{1}, \mathrm{X}_{2}\right.$ dan $\left.X_{3}\right)$ secara simultan terhadap variabel dependent $(\mathrm{Y})$. Kompetensi guru $\left(\mathrm{X}_{1}\right)$, komitmen kerja $\left(\mathrm{X}_{2}\right)$ dan motivasi kerja guru $\left(\mathrm{X}_{3}\right)$ mempunyai pengaruh positif yang signifikan terhadap kinerja guru $(\mathrm{Y})$, hal ini dapat terlihat dari nilai Fhitung $=$ 32,686 dan nilai sig $=0,000(\mathrm{p}<0,05)$. Hipotesis keempat "Kompetensi guru, komitmen kerja dan motivasi kerja bersama-sama berpengaruh terhadap kinerja guru di SMP-SMP Negeri andalan di Kabupaten Sleman" terbukti kebenarannya.

Pembahasan

Hasil penelitian ini menunjukkan bahwa skor total kinerja guru sebesar 85,91 sehingga dapat dikatakan bahwa kinerja termasuk dalam kategori cukup. Kinerja guru dipengaruhi oleh kompetensi guru, komitmen guru dan motivasi kerja guru baik secara sendiri-sendiri maupun bersama sama. Peningkatan kinerja guru tidak sebatas memperbaiki dalam mengajar di dalam kelas atau di sekolah, tetapi lebih dari itu guru dapat menjadi katalisator, motivator dan dinamisator pembangunan, dapat memberikan nilainilai yang berisi pengetahuan, pilihan nilai hidup dan komunikasi dengan masyarakat. Pengetahuan yang diberikan kepada anak didik harus mampu membuat anak didik pada akhirnya memilih nilai-nilai hidup yang semakin komplek dan harus mampu membuat anak didik berkomunikasi dengan sesamanya di dalam masyarakat.

Rata-rata skor total kompetensi guru sebesar 87,85 sehingga dapat dikatakan bahwa kompetensi guru termasuk dalam kategori cukup baik. Kompetensi guru berpengaruh positif $\left(\mathrm{b}_{1}=0,380\right)$ dan signifikan $(\mathrm{p}=0,000)$ terhadap kinerja guru. Apabila kompetensi guru meningkat maka kinerja guru juga akan semakin baik, begitu pula sebaliknya jika kompetensi guru semakin berkurang maka kinerja guru juga akan semakin menurun. Kompetensi yang dimiliki oleh setiap guru akan menunjukkan kualitas guru yang sebenarnya. Kompetensi tersebut akan terwujud dalam bentuk penguasaan 
pengetahuan, keterampilan maupun sikap profesional dalam menjalankan fungsi sebagai guru.

Rata-rata skor total komitmen kerja sebesar 68,66 sehingga dapat dikatakan bahwa komitmen kerja termasuk dalam kategori cukup baik. Komitmen kerja berpengaruh positif $\left(b_{2}=0,325\right)$ dan signifikan $(p=0,000)$ terhadap kinerja guru. Apabila komitmen kerja meningkat maka kinerja guru juga akan semakin baik, begitu pula sebaliknya jika komitmen kerja semakin berkurang maka kinerja guru juga akan semakin menurun. Komitmen guru terhadap tugas, profesi ataupun komitmen terhadap sekolahnya dibutuhkan agar guru bersangkutan bersungguh-sungguh dalam menjalankan tugasnya. Komitmen guru yang tinggi akan menjadikan guru bersangkutan memiliki kinerja yang tinggi pula. Hasil penelitian ini sejalan dengan Rosita Bestiana (2012) yang menyatakan ada hubungan antara komitmen dengan kinerja guru SMP Negeri 1 Rantau Selatan Kabupaten Labuhan Batu.

Rata-rata skor total motivasi kerja guru sebesar 110,87 sehingga dapat dikatakan bahwa motivasi kerja guru termasuk dalam kategori cukup baik. Motivasi kerja berpengaruh positif $\left(b_{3}=\right.$ $0,262)$ dan signifikan $(p=0,000)$ terhadap kinerja guru. Apabila motivasi kerja guru meningkat maka kinerja guru akan meningkat begitu pula sebaliknya apabila motivasi kerja guru menurun maka kinerja guru akan menurun. Temuan penelitian ini sejalan dengan pendapat Performance (kinerja) adalah hasil interaksi antara motivasi dan ability (kemampuan). Motivasi pada dasarnya karakteristik psikologi manusia yang memberikan kontribusi pada tingkat komitmen seseorang. Ini termasuk faktor yang menyebabkan, menyalurkan, dan mempertahankan tingkah laku manusia arah tekad tertentu. Oleh karena itu dengan memberikan rasa memiliki organisasi kepada guru, berarti akan memberikan dorongan kepada guru untuk mengerahkan kemampuan, keahlian dan keterampilannya dalam melaksanakan tugas dan kewajibannya.

\section{PENUTUP}

Simpulan

Berdasarkan hasil pembahasan di atas, simpulan yang dapat ditarik dari penelitian yang telah dilakukan adalah adalah sebagai berikut :

1. Kompetensi guru memiliki pengaruh positif dan sifnifikan terhadap kinerja guru di SMP-SMP negeri andalan di Kabupaten Sleman. Peningkatan kinerja guru dapat dilakukan dengan meningkatkan kompetensi profesional, kompetensi pedagogik, kompetensi kepribadian dan kompetensi sosial.

2. Komitmen guru memiliki pengaruh positif dan sifnifikan terhadap kinerja guru di SMP-SMP negeri andalan di Kabupaten Sleman. Peningkatan kinerja guru dapat dilakukan dengan meningkatkan komitmen terhadap proses belajar mengajar, kurikulum dan kebijakan sekolah.

3. Motivasi kerja memiliki pengaruh positif dan sifnifikan terhadap kinerja guru di SMP-SMP negeri andalan di Kabupaten Sleman. Peningkatan kinerja guru dapat dilakukan dengan meningkatkan usaha individu, daya tahan/keuletan, sasaran kerja, kepuasan kerja, gaji yang diterima, kualitas pengawasan, hubungan antar teman sejawat, kondisi kerja dan keamanan fisik. 4. Kompetensi guru, komitmen guru, dan motivasi kerja bersama-sama memiliki pengaruh positif dan sifnifikan terhadap kinerja guru di SMP-SMP negeri andalan di Kabupaten Sleman. Apabila kompetensi, komitmen kerja, dan motivasi kerja ditingkatkan maka kualitas kerja, kuantitas kerja, ketepatan waktu dalam pelaksanaan, kehadiran dan inisiatif juga akan cenderung meningkat.

Saran

Berdasarkan hasil penelitian yang diperoleh maka disarankan beberapa hal sebagai berikut: 
1. Bagi guru SMP-SMP negeri andalan di Kabupaten Sleman lebih memperhatikan kompetensi, komitmen maupun motivasi kerjanya dengan cara melanjutkan pendidikan ke strata yang lebih tinggi, mengikuti berbagai pelatihan, termasuk pelatihan motivasi, serta menambah wawasan dan pengetahuan. Komitmen guru masih harus ditingkatkan karena belum termasuk ke dalam kategori baik.

2. Bagi pengelola sekolah SMP-SMP negeri andalan di Kabupaten Sleman agar memberikan kesempatan bagi guru-guru untuk mengembangkan potensinya serta memotivasi guru dalam berkerja.

\section{DAFTAR PUSTAKA}

Azwar, Saifuddin. (2003). Penyusunan Berskala. Yogyakarta: Pustaka Pelajar Offset.

Colcuitt, Jason A, Jeffery A. LePine, \& Michael J. Wesson. (2009). Organizational Behavior, Improving Performance and Commitment in the Workplace. New York: McGraw-Hill Company.

Hadiyanto. (2004). Mencari Sosok Desentralisasi Manajemen Pendidikan di Indonesia. Jakarta: Rineka Cipta.

Hinkle, D.E., Wiersma, W. \& Jurs. S.G. (1979). Applied Statistics for the Behavior Science. Boston: Houghton Mifflin Company.

Katsva, M. \& Condrey S. E. (2005).

Motivating personnel at Russian nuclear power plants: a case-study of motivation theory application, Public Personnel Management. Volume 34 No. 4 Winter 2005 page 343-356.

Mulyasa. (2009). Standar Kompetensi dan Sertifikasi Guru. Bandung: PT. Remaja Rosdakarya.

Purwo Susanto. (2010). Pengaruh kompetensi dan motivasi kerja terhadap perilaku profesional guru di SMK Gajah Mungkur 1 Wuryantoro Kabupaten Wonogiri. Tesis. Universitas Negeri Semarang.
Rosita Bestiana. (2012). Hubungan Kepuasan Kerja, Motivasi dan Komitmen Normatif dengan Kinerja Guru SMPN 1 Rantau Selatan Labuhan Batu, Jurnal Tabularasa PPS UNIMED, Vol.9 No.2, Desember 2012, hlm 187-200.

Sugiyono. (2008). Metode Penelitian Kuantitatif Kualitatif dan $R \& D$. Bandung: CV. Alfabeta.

Westerman, J.W., \& Simmons, B.L. (2007). The effects of work environment on the personality performance relationship: an exploratory study. Journal of Managerial Issues, Vol. XIX Number 2. 288-305. 